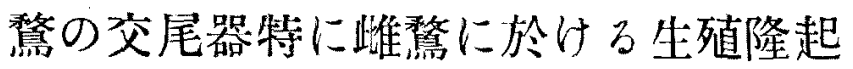 \\ (Phallus) の痕跡 (Rudiment) に就て
}

橋本重 郎

(宮筑高等農林學校)

\section{緒霉}

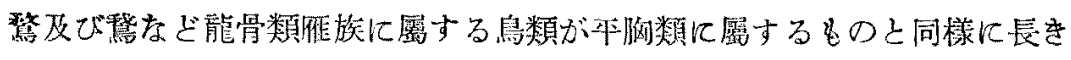

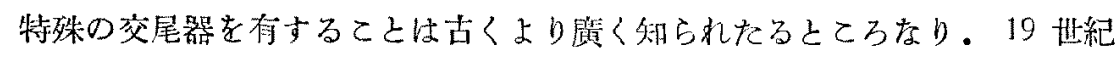
の初めに於て既に愁のぺニス(Penis)に就き解說せられたるるのあり，且つ そのペニスは翰精管之直接の速絡を有せざることも明か机示さる。その後多

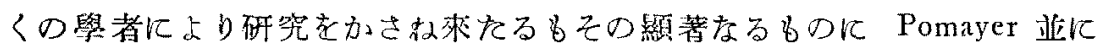
Liebe の研究あり。

Pomayer (1902) は Fleischmann の有羊嗼類に於ける總排泄腔及びフアー ラスの研究の一部として，主として登及で稆の類のフアーラスの發生に就て

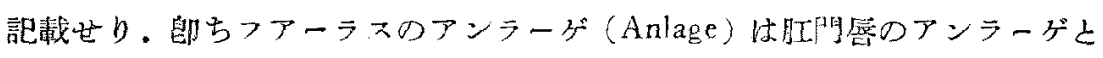

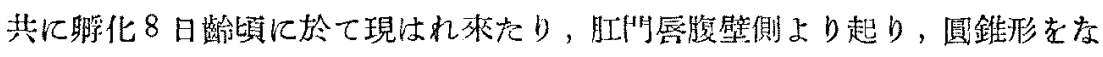
し明かに桇起として認めらる・ファーラスの內面には縱沉走るとてろの一つ の瑇あり，その一端はフアーラスの先端中央部に了り，他端は深く奥に入り

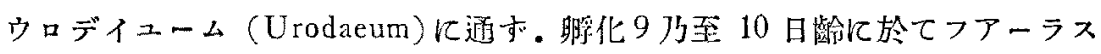

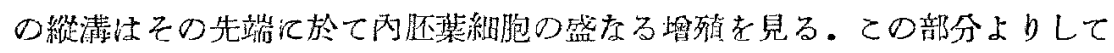

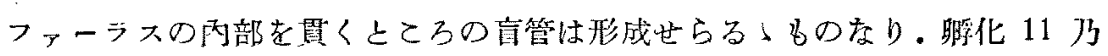

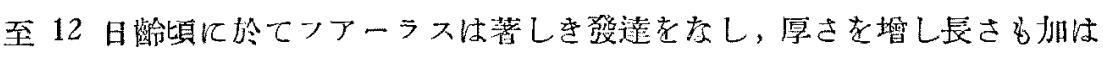
り，肛閃外に突出し柬をる。乙の時期に至ればフアーラスはもはや單なる圆 錐形にはあらすして捻轉し始的烏類のペニス特有の蝶旋跃の形態形成の傾向 を現はす。同糕にしてフアーラスの先端より內部に入るとてろの盲管を揄轉

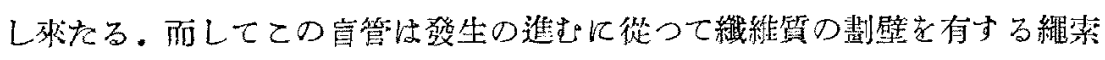

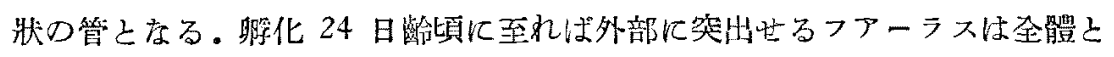


して副肛門唇之其にクロアカ（Cloaca）內に陷入し始む。䁔化當日には全く

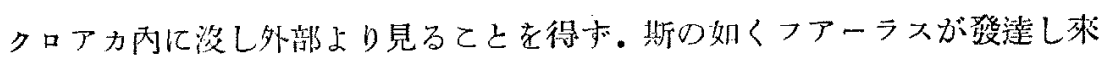
たりペニスが完成せらるっものなるが，この生殖突起なるもの」アンラーゲ

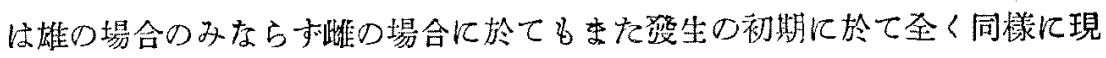

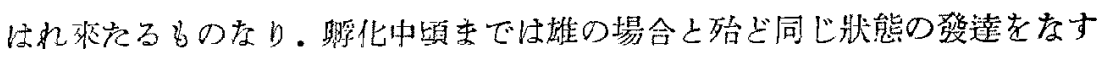
ものにして，雄のフアーラスと同栐にその特有の缧旋狀の形態形成の傾向を 示す.吻諭その大さに於ては雄のものに比して極めて小なり．而してての埸 合はその後雄の場合に於けるが如く發逘し來たるものならざれに゙も，また全

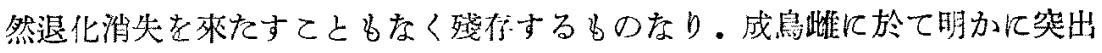
せるクリトリス (Criloris) としてクロアカ内殘存するを認むるてとを得。

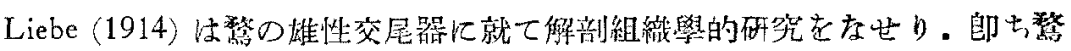

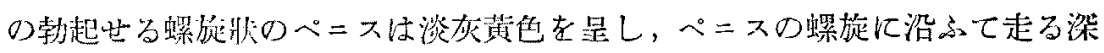

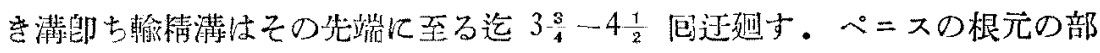
分プロクトデイユーム (Proctodeum) の腹側壁に於て稌精满老境に左右に分 かれ二つの膨隆せる裙篦に了る。乙の膨隆部は头側のもの大にして右側のる の小なり・ペニスはての左右二つの膨隆部が對索なして仲長せるものなるる， この大なる左側の膨㺯がペニスの大部分をなすことっなる。輸精溝はウロデ

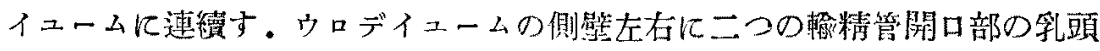
乫起存在士。精液は先づウロデイュームに射出され，それより榆精溝に流れ 达子ペニスの先端に李で導かるつものなり。ペニスの根元の膨隆部及び輸精

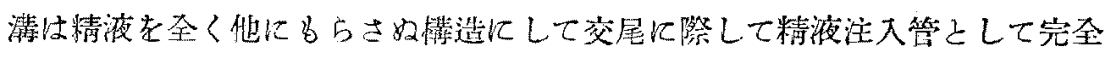
に役立つ・ペニスの表面花被ふとてろの粘膜は基の部分に於ては录かなるも，

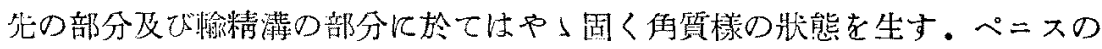

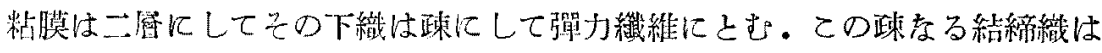

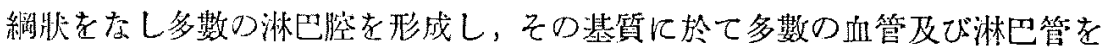
含有すペニスの勃起はての部分上り淋巴液が淋巴腔に推しHさる」ことに

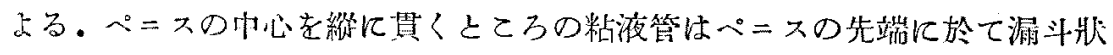
をなして開口し，他端は內部に於て目端に了る。その內面は細かき襀を形成 
し一層の腺細胞に被はる。その腺細胞の制雖さるものが粘液に變化し本をる。 而してての粘液はペニスが反轉勃起する祭それが滑かに行はる」ために役立 つ、ペニスの表面に於ては全く粘液を分泌せず。整のペニスの神經器官は㨄 乳動物の交尾器の皮膚に發見せらる」如き細小體の形態としての終末小體を

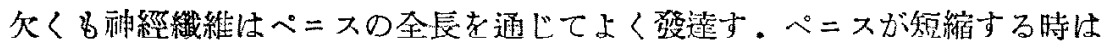

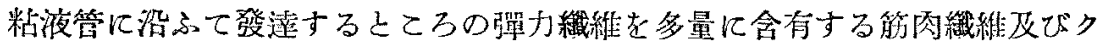
ロアカ壁の筋肉の働きによる。粘液管は明折してぺニス全噌を中に引き込み， またぺニスの表皮の彈力性により完全にまくれ込み，根元の左側の膨隆の冈 部におさまる。

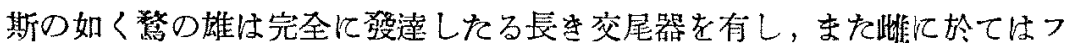

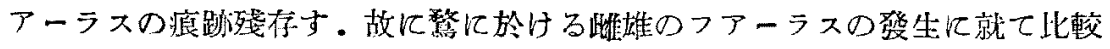
し且つその組織棈造を詳紐に研究して，成鳥崔に殘存するところのクリトリ スに及ぶことは與味ある問題なりと信な゙。

\section{實 驗 材 料}

賽驗に供したる材料は北京種，青首程及びカーキーキアンベル種の三種な D.

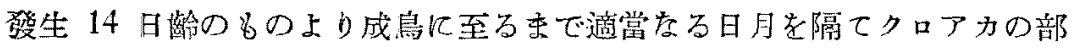
分老採取し，フォルマリン4\% 液，10\% 液及び Allen-Bouin 液にて固定す。

成鳥のペニスは项部動脈切斷屠殺に際して自然に勃起したるものあり．ま た全く勃起せざりしるのはピンセツトを用と静かに反轉せしさ。

\section{發生時に於ける睢雄のフアーラスに就いて}

睬化 14 日路胚體に於けるフアーラスはその外部より見たる大さ呲雄に於

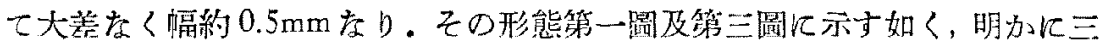
つの部分上り成り，先端は丸く所謂頍部を形成し，その基部は左右に區分せ らる.基部在右に分つところの溝は頍部にまで及び他端は深く內部に入る。

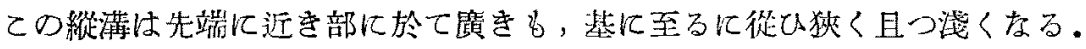
而してフアーラス全體として（動物體自體より胃て）右爸に捻轉する傾问を 現はす．乙の揄轉の現象は雄の場合に特に頱著にして，第三圖に示す如く，

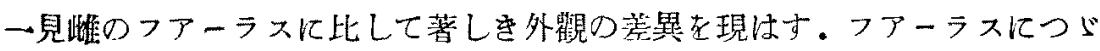


くところのクロアカ腹例壁膨隆部は第一圖に示す如く所買根部を形成し深く

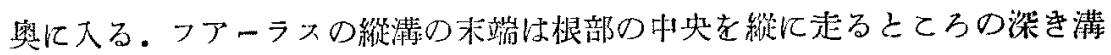
に殆ど一直線をなして連絡すフファーラスの粘膜は第二十三乃至二十五國に

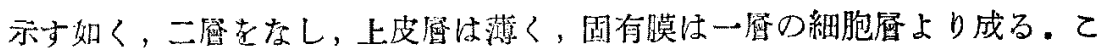

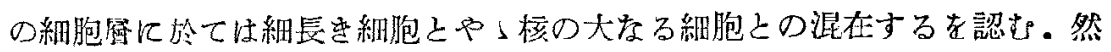

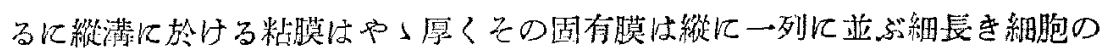

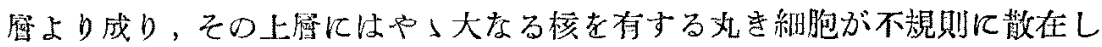
次第に上皮に移行す．粘膜下織は概して密なるも所ふに小腔淂認めらる。乙

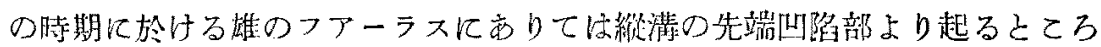
の管跃老なす粘膜が第二十五圆に示す如く，フアーラスの中心縱に貫き發

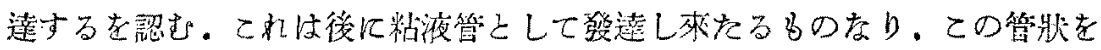

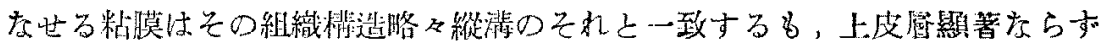

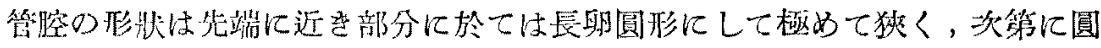

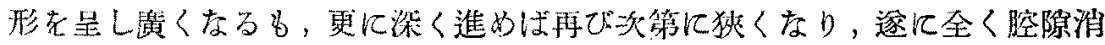
失して狊端となる。而してての岢管の方向はフアーラスの先端よりや小科左

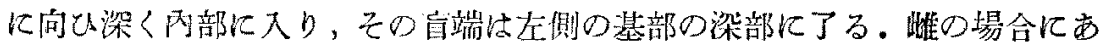
りては第二十四圖に示す如く。ての盲管は顯藷ならず，且つそのフアーラス

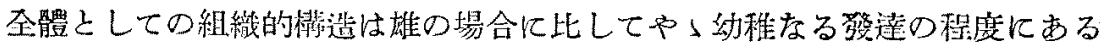
bの+如L.

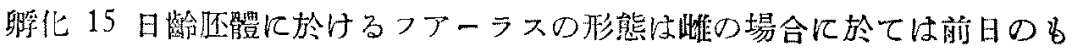
のと大差なけれども，乙れに反して雄の場合飞於ては第十二圖に示す如く， 著しくその大さを塯し，またフアーラスの表面特に頭部て於て四凸の触を生 和る孝認む。從つてその形態は雌のbのに比して高か甚しく異るに至る。

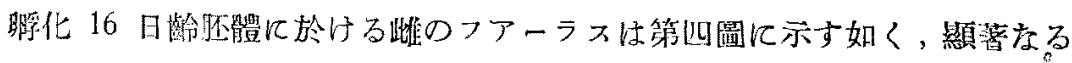

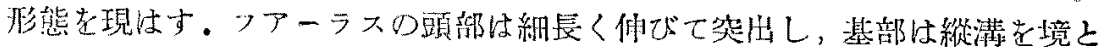
してた右殖ど均等の形態となる。恰名哺乳舸物の發生の初期に於ける生殖突 起上全く類似の形態を現はす。郎占頭部はクリトリスにして, 左右の基部は

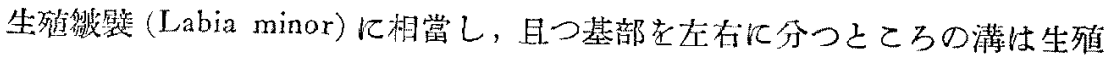
满に一致す、而して雌のフアーラスはこの時期に於てその揄轉の傾向全く止 


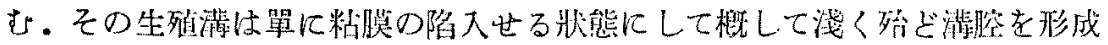
せす、生殖清の先端より起るとてろの简管組織は呲の場合に於てもフアーラ スを翼き初めて形成せらるっを認む。その方向は雄の場合と同樣先端上りや

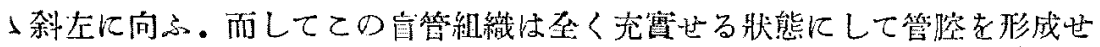

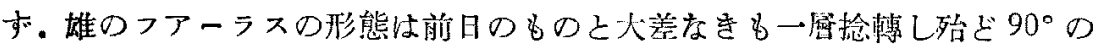
捻轉を示す，從つてその生殖瀞は先端に至るまで $1 / 4$ 回过迴するてと」なる。

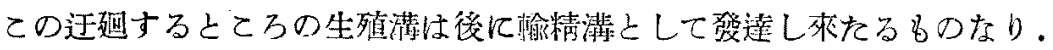

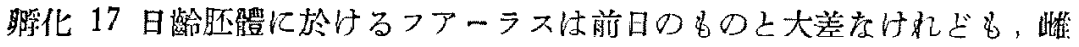
の場合に於ては肛門唇の發達に比例してや小增大し來たるを認む，乙の基部 に於ける幅約 $0.7 \mathrm{~mm}$ となる。雄の場合に於てはフアーラスの全體として益

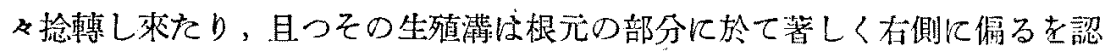
む.從つてそれが根部の縰淟につがく部分に於て曲折するに至る。

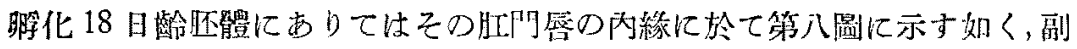

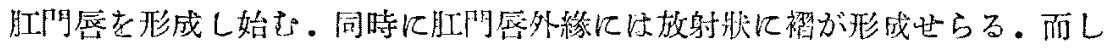
てフアーラスは雄に於て第八圖及び第十三圖に示す如く，更に㙷著なる形態

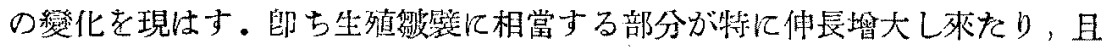
つ先端に於て著しく捻轉し明かに鳥類のぺンス特有の螺旋狀の形熊を現はし

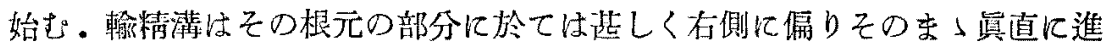

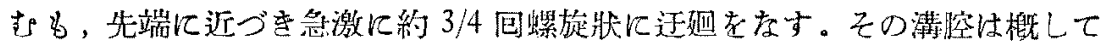
廣きる，最先端部に於ては單に粘膜》陷入したる状態にして，比较的厚を上皮

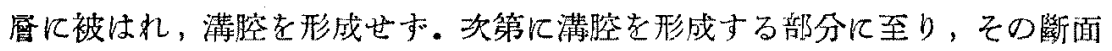
はV字形をなし，それがU字形に變り，再び V字班圭呈し，次に真直の部 分に入る。乙の眞直の部分に於てはや〉廣を德利形の䅉腔を形成し，根元に 進むに從ひ，德利形の底に當る部分飞於て，粘膜固有膜の上屡汇や」大るる

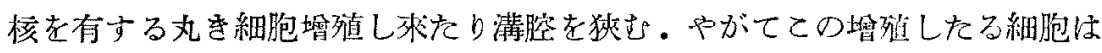

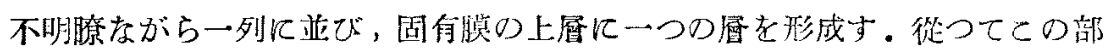

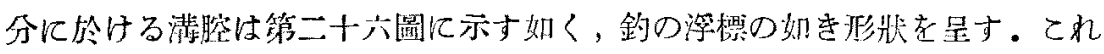

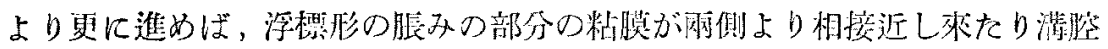




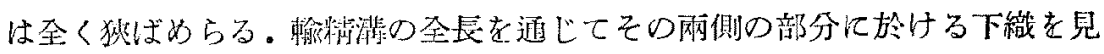

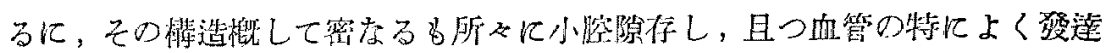
し来たる走認む。粘液管の粘膜はその固有膜にありては縱に一列に並ぶとて

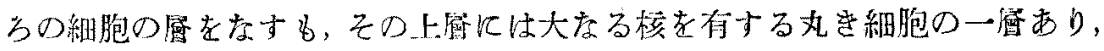
全體として明か儿二符のや小湟き粘膜を形成す。從つて管腔は甚しく陝ばめ られ，上皮層の墢洼㙷藷ならざるも，屡々全く管腔消失の狀態を現はす。

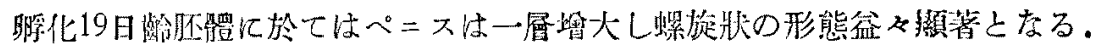
てれれ反して雌のフアーラスは㱠ど前日のものと同樣にして, 形態上の變化

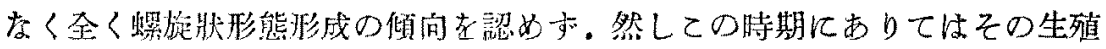

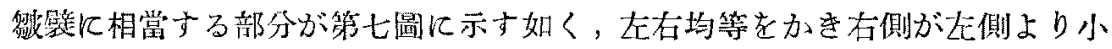

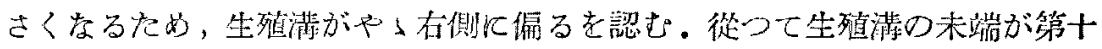
五圖に示す如く，根部の縱清につよ゙く部分に於て喰違ひ毫生ずるに至る。

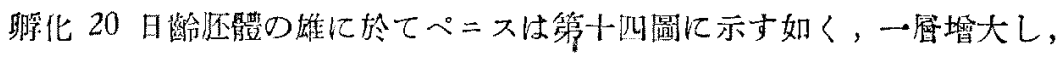

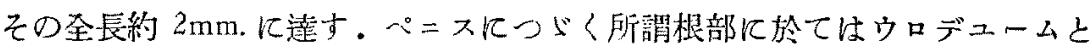
プロクトデューム上老境するところの膨隆部老形成し始め，奧に於て多數の

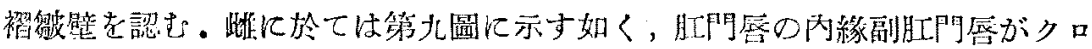

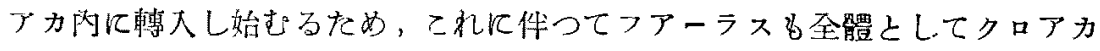
內に陷入する倾向を示す，從つてフアーラスの先端恃尾側に向つて轉心，そ

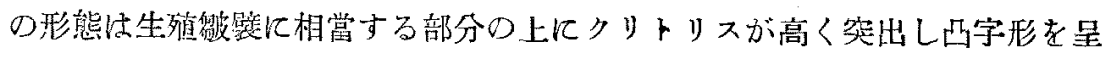

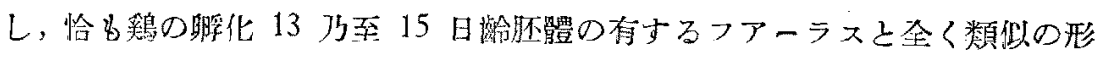
態を現はす。

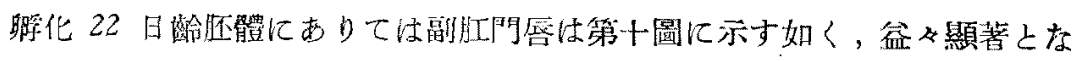
る。而して雄に於てはペニスは第十圖正で第十六圖に示す如く，全く蠌旋状

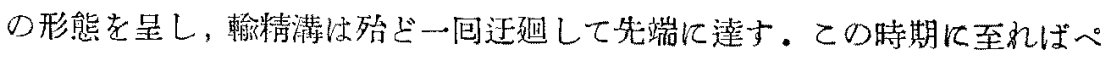
ニスは先端の粘液管開口部に於て第十圖に示す如く，次第にまくれ込子始む るを認む。而してペニスにつがく根部に於しは第十六圆に示す如く，朋かに ウロデューム プロクトデュームとを境するところの槛砝膨隆部老形成す。

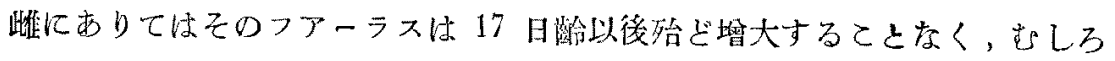




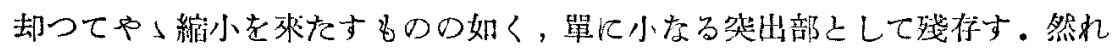

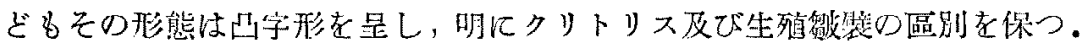

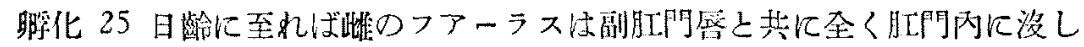
極めて小なる婴出部として殘存するる，第十八圖に示す如く，明加にその特

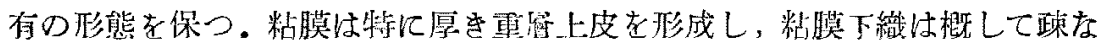

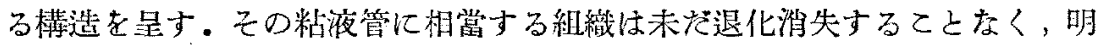
か化存するb，全く管腔を形成するととなし．而してファーラスにつぐく 根部に於ては雄の場合と同樣にウロデュームとプロクトデュームとを境する

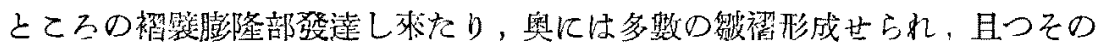

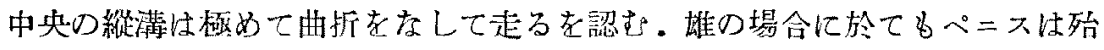

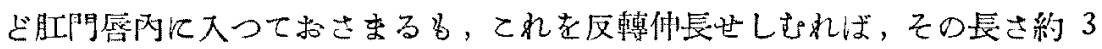

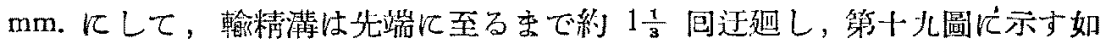

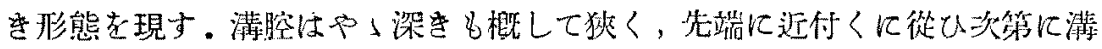
貯渻失し，單に粘膜の陷入せる状態となり，表面は全く本滑なる上皮に被は る。ペニスの粘膜は第二十七圆に示す如く，乙の固有膜の上屈に大なる核を

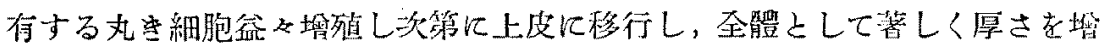
す。粘膜下織はや小践となり特て輸精瑇の雨側の部分に於ては所マに小腔腺 多く，乙の部分は後に網狀組織となり淋巴腔を形成する部分に相當す。粘液 管はこの柾なる組織の更に深部に存在す。粘液管の周壁をなすところの結繶 䇅は第二十七七圖に示す如く，二層をなし，管粘膜に接するものは小なる丸き

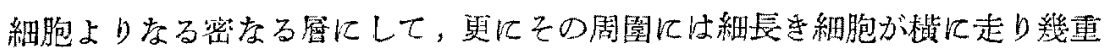
にる处ぐり厚き層老形成す。

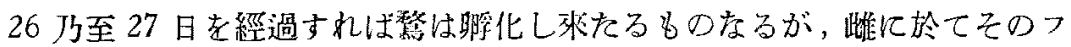
アーラスは明かれ凸字形の小突起部としてクロアカ内に殘存す．乙の大さ郎 ら高さ及で基部の幅は共に䄪 $0.5 \mathrm{~mm}$.なり。乙の時期に至れば雄の場合に於

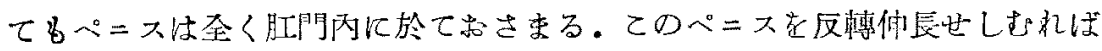

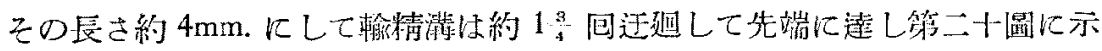

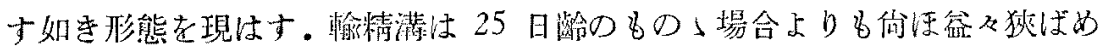




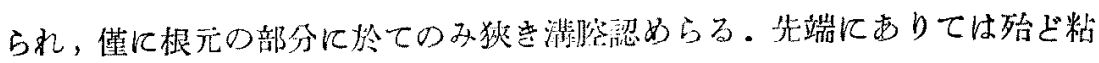

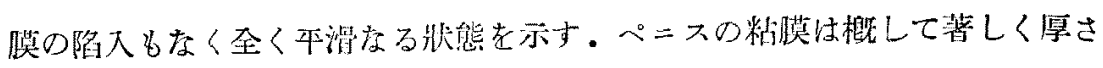

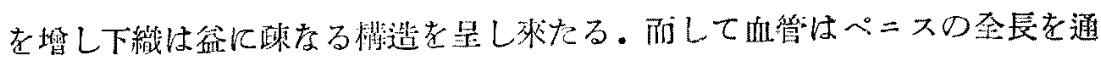

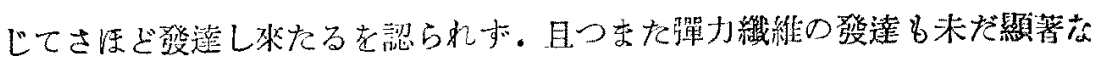
らす。

\section{卯化後に於けるベニスの發墱に就いて}

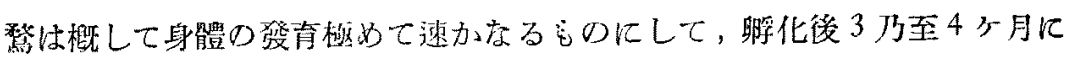
て，その大さ殆に゙成鳥大に淦し，踾重なども相虽に重く，青首栕に於ては 1.8

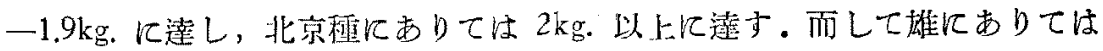

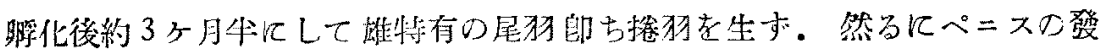

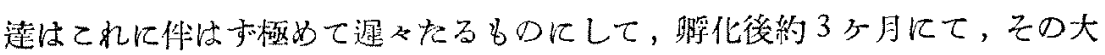

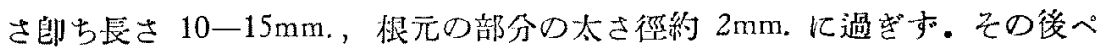

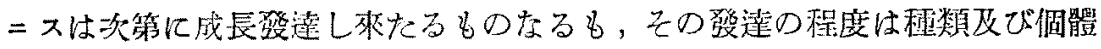

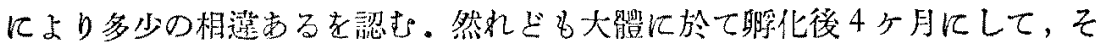

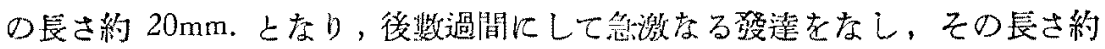

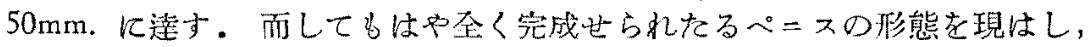
粘膜の装面には根元の部分に於てのみら和先端に近き部分に至るまで特有の

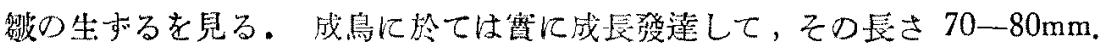

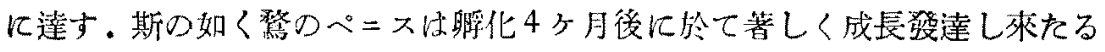

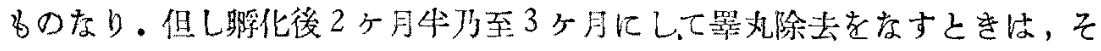

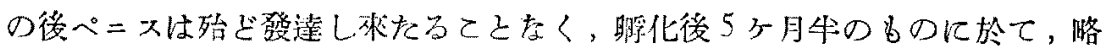

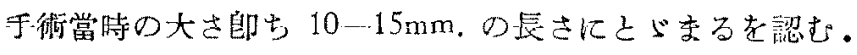

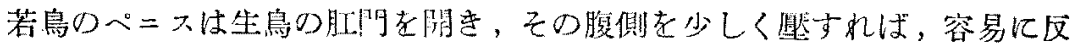

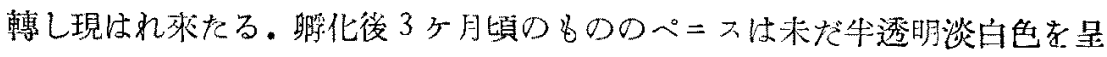
し，その先端に於て，第二十二國に示与如く，表面頗る滑加をるも根元に至

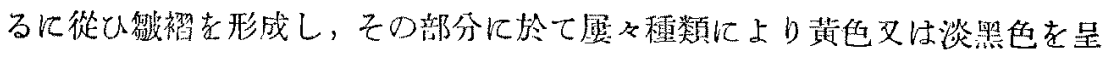

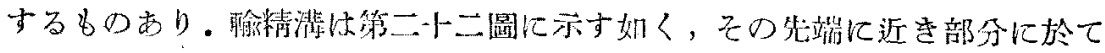

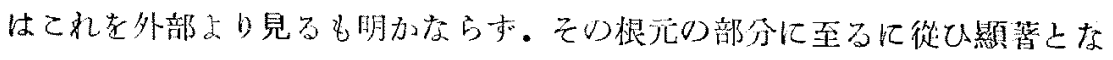




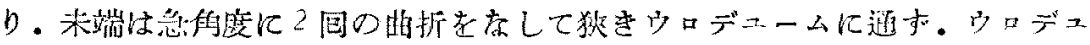

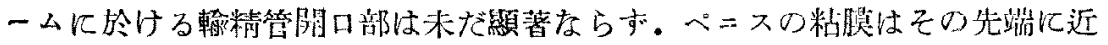

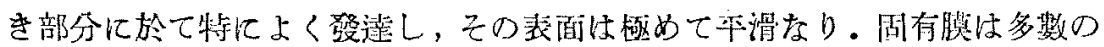

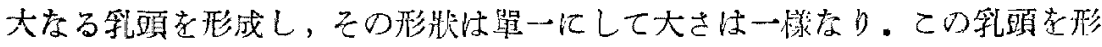

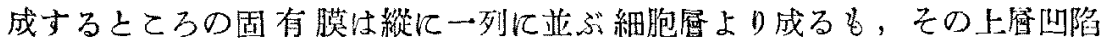

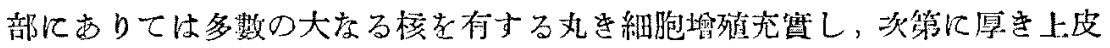

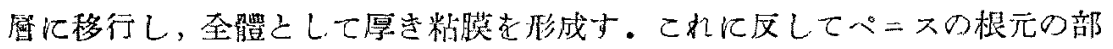

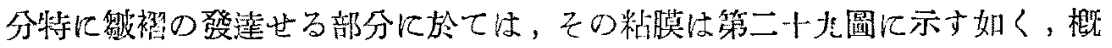
して溥き常とす。而してその固有膜は極路て小なる乳頭を形成し，その形

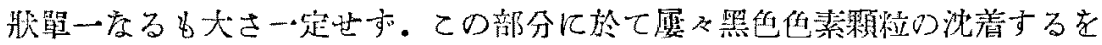

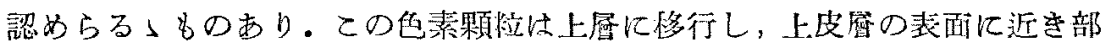
分江然ては所ぬに集園をなすととあり。

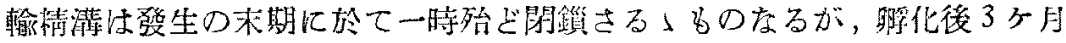
を經過せるての時期に至るる未だ满膑の再び形成せれ来をるを見す.特に先 端の部分に於ては表面平滑なる上䈐に被はれ單に粘膜固有膜の陷入するを認 むるのみ，而してての陷入せる固有膜に於ては全く乳頭老形成するこ上なし．

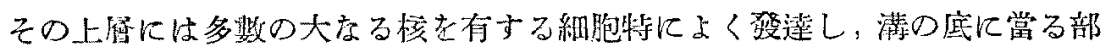

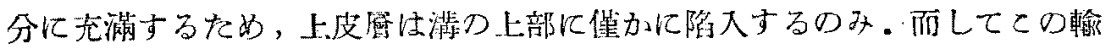
精满の組織は睬化後 3 ケのペニスに於ては先端に至るまで $2 \frac{1}{2}$ 回の螺旋狀 迁通をなすを認む。

粘膜下織はよく發達し來をるも，概して蹯にして，特に輍精满の兩側の部

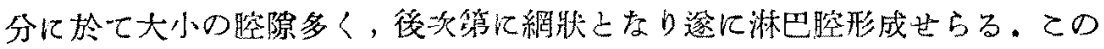

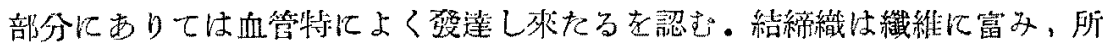

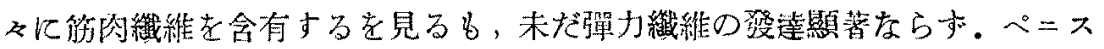
の根元に近を部分に於ては，之の眯后る下織內に第二十九圆に示寸如く，神

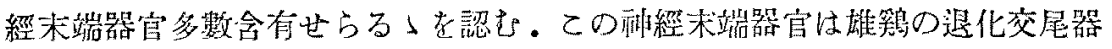

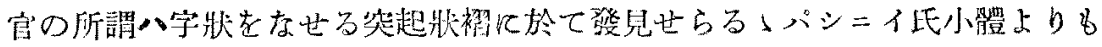

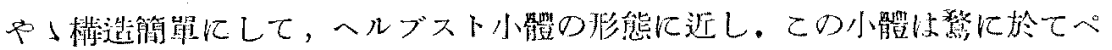




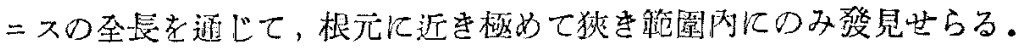
ペニスの中心を縱に賁くところの粘液管の管腔はや小噟く發洼するを見る も，その全長の略々中間部に於て少しく細く，而してまた椯に至り再で細

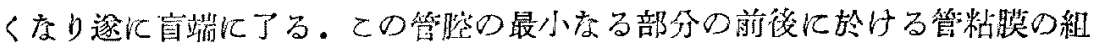

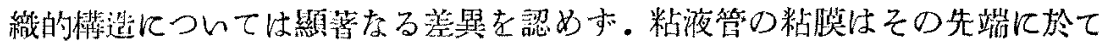

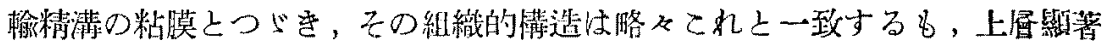

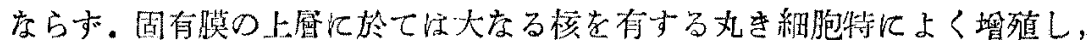

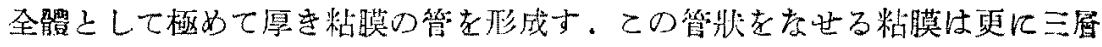

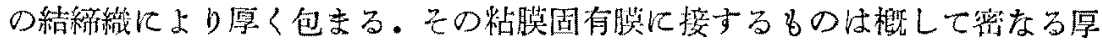

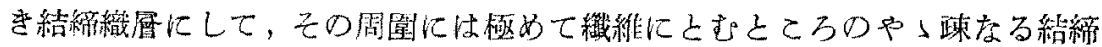

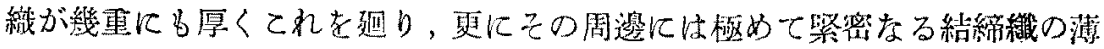

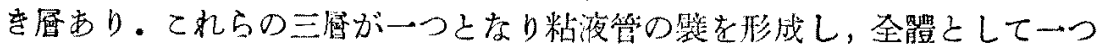
の粘液管が形成世らるいてといなる。

成鳥の完成せるぺニスにありては粘液管の壁をなすとてらのてれらの三底

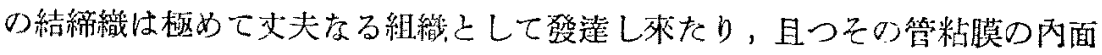

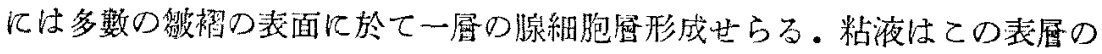

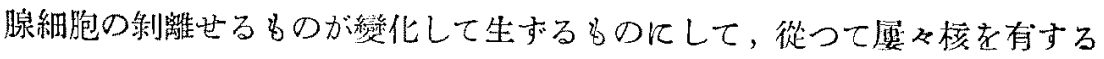

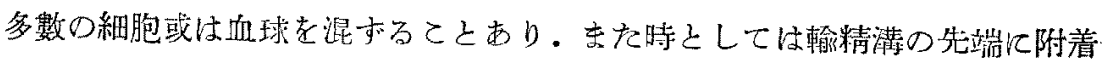
せる精液が混入し棑たるため，この粘液中に多くの精系を發見することあり。 ての粘液管は網狀をなすところの淋巴腔に接し，且つその一側に於ては管の

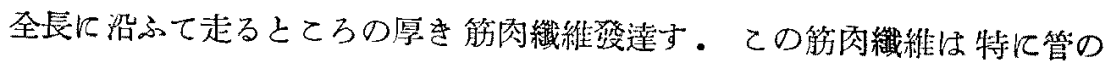
吉端及びそれに近き部分に於て上く墢達す，管の盲端に了る部分には，近く 殆どてれに接して横はるとてろの筋肉磨あり，恰もクロアカ冈ウロデニーム

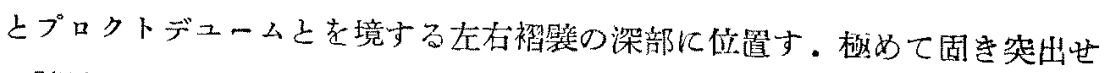

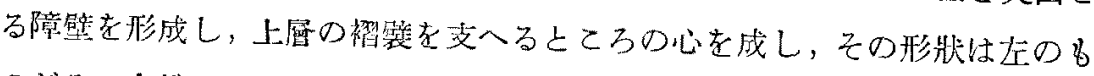
のがその右端下方に胆がり右のものがその左端上方に向儿，その左右の曲線

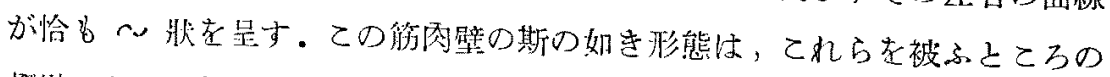

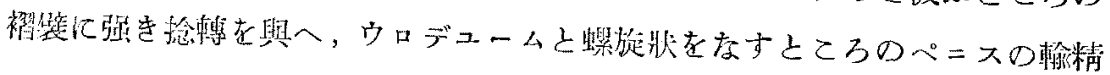




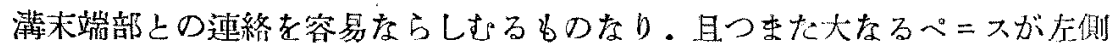

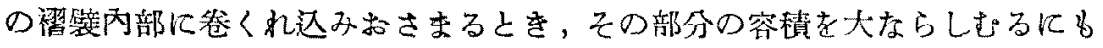
役立つてとっなる。

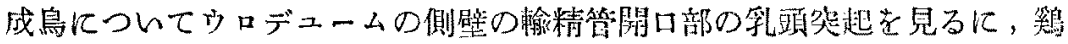
のそれに比較して遥に小なるを認む。

\section{篎化啳に於ける昆のフアーラスのルデイメントに就て}

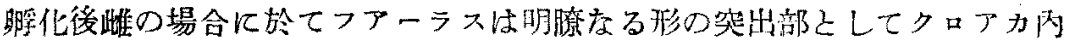

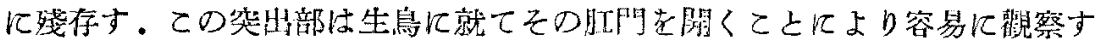

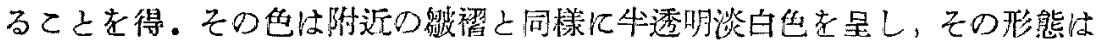
第二十圖江示す如く，頭部及び左右の基部の三つの部分に明示に區別さる。 頭部はや〉紏長く，基部は右側が左側より少しく小なるも，頭部は基部の上

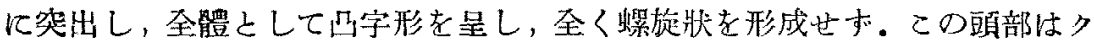

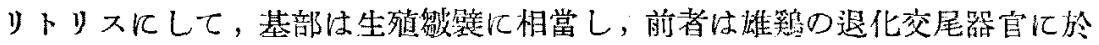
ける中央の丸を突起郎ち白色體に一致し，後者はその网側の所謂八字狀をな

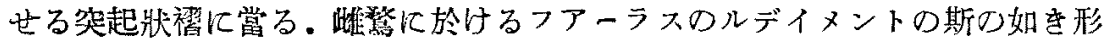
態は孵化前のものと全く同一にして，更に形態上の變化發拈をなざ゙るとと

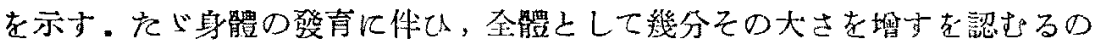
み.瞬化後 3 少の8のに於ては，その大さ毁ち高さ及び基部の幅共に約 1.5 $\mathrm{mm}$. KLて，成鳥にありては高さ約 $2.0 \mathrm{~mm}$. 基部の幅的 $2.5 \mathrm{~mm}$. 存り。但

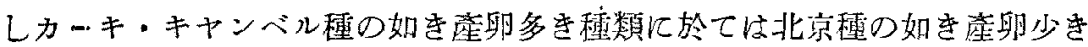
ものの場合に比して，その形や小小なり・カーキ・キャンベル譒の肚門は大

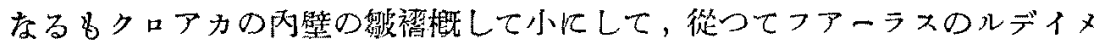

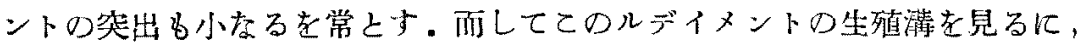

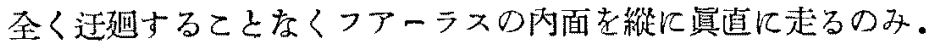
このルデイメントの粘膜は第三十圆に示す如く，その袁面極めて平縎にし てクロアカ內の他の部分と同樣厚重層上皮を形成す，固有膜はクリトリス

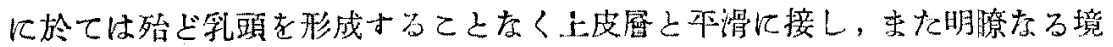

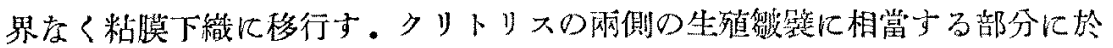




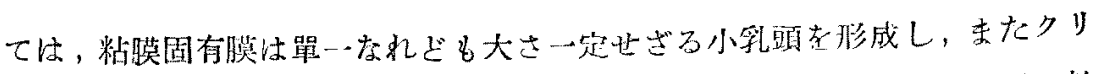

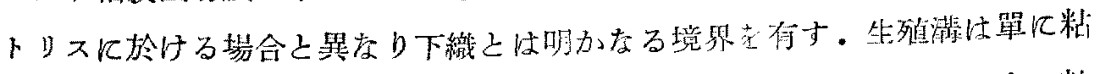

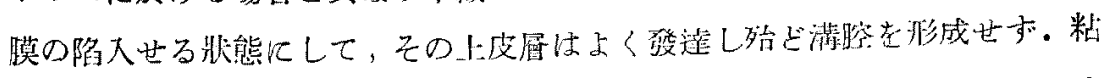
膜下織は堆鴙の退化交尾器官の場合に比校しては概して密なるも,クリトリ

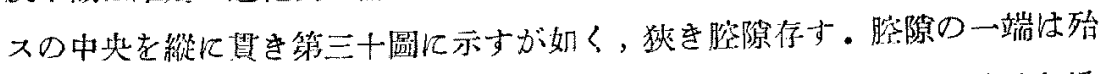

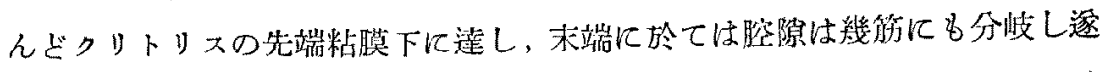

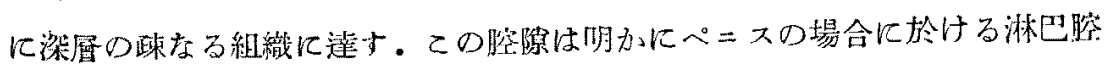

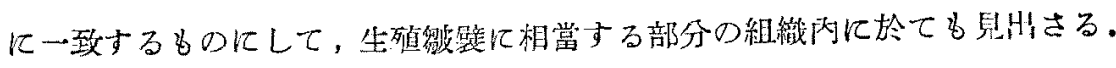

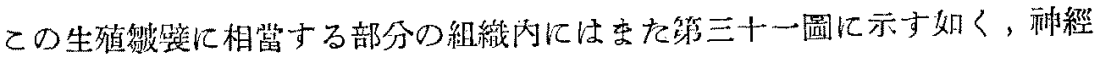
末端器官へルブスト (Herbst) 小體發見せらる. その數可なり多く，耏して

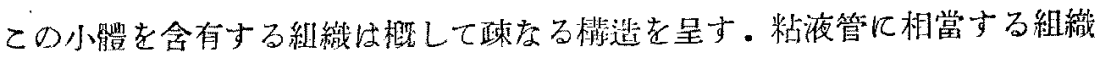

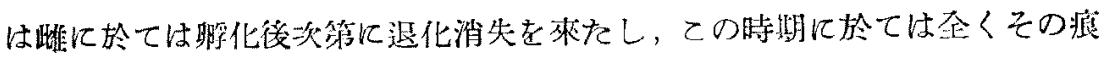
䟞老当認さる老得市。

\section{總括}

（1）䓡の雄の有する大なる長きぺニスは發生の初期に於てフアーラスと してクロアカ開ロ部に現はれ來たる。てのフアーラスは雄のみなら亦雌の場

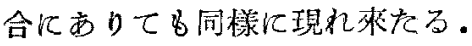

（2）フアーラスは明かに三つの部分上り成り，哺乳動物の發生の初期に

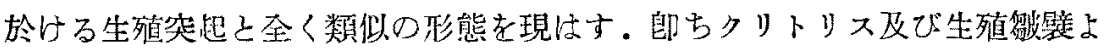

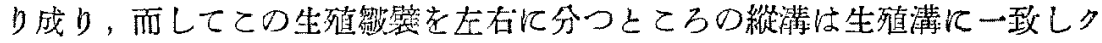
リトリスにあで及ぶ。

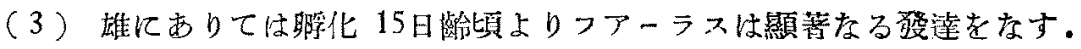

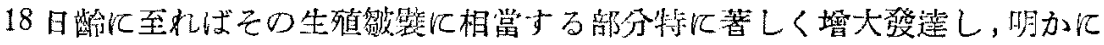
鳥類のペニス特有の蝶旋秋の形態老現はし始む。而して生殖溝は輸精腔とし

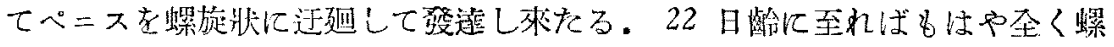

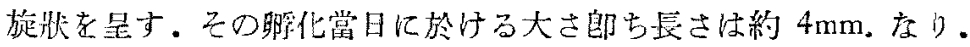

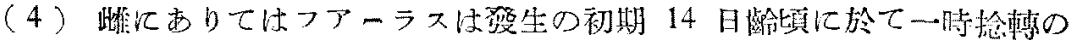

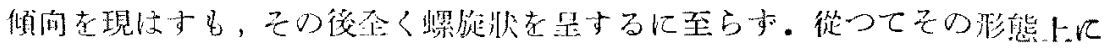




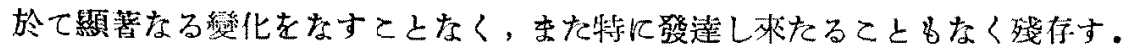

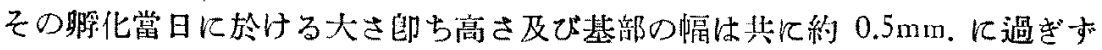
成启雌に於けるそのルデイメントを見るに，形態は睬化前のものと緵りなく 凸字形の突出部として存す。

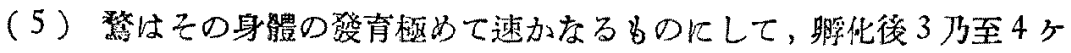
月にて，その大さ殆ど成鳥大に澾し，䯏重も相當大なるる， ベ二スの發達は

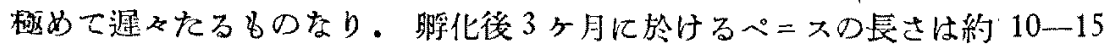
$\mathrm{mm}$.几過ぎす。而してその媵4 万至 5 ケ月に於て急激なる發達をなするのな

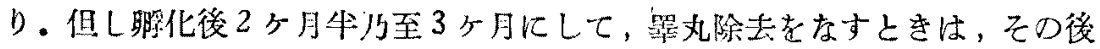

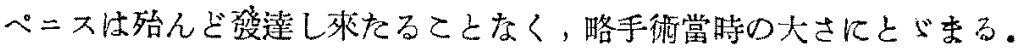

（6）ぺニスが勃起するに際してその心考なところの粘液管は笅生の初

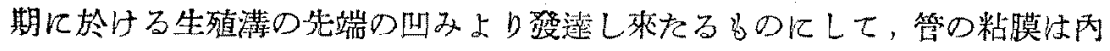

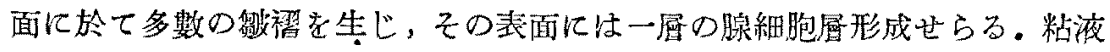
はての表瓷の制離せるものが變化して生ずるるのにして，從つて屡々核を有

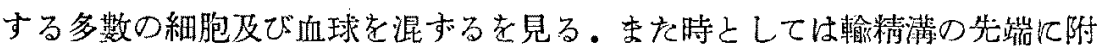
着せる精液が混大し來たるため，乙の粘液中に多数の精系を發見することあ り.ての粘液はぺニスの勃起に際して，それが滑かに行はるらをめに役立つ 各のなり。

（7）粘液管は嶉の場合に於ても發生中にありてはフアーラスの組織內に

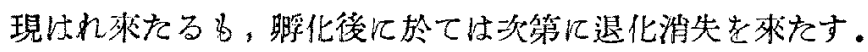

（8）蹸の場合に於けるフアーラスのルディメントにありても，その組織 內に明加に淋巴貯の痕跡の存在するを認む。

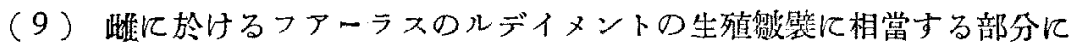
ありて並に雄の場合に於てはぺニスの根元に近き極めて小なる部分にありて その組織內に多數の神經末端器官 Herbst 小體を含有する老認む。

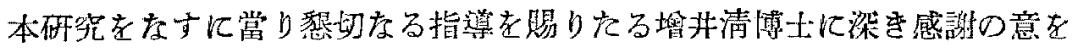
表す。 


\section{文㱆}

Fleischman, AlbFrt: Morphologischen Sludien iber Kloake und Phallus det Amnioten, Morphol. Jahrb., Vol. 35, 1902.

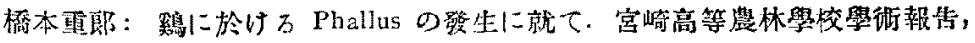
第二㫘虎， 1980 .

LimBe, Watther: Das männliche Begattungs Organ der Hausente. Jenaische Zeitsch. Naturwissen. BA. 51, 1914.

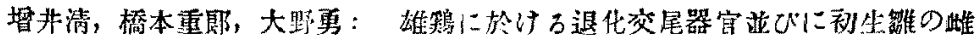

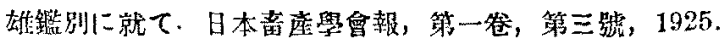

\section{附 圖 說 明}

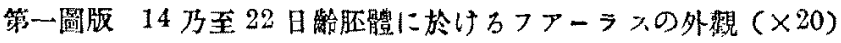

第 - 14 日路 우

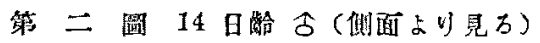

第三圈 14 日敖合

第四圆 16 日路是

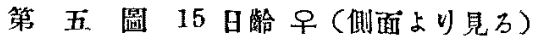

第 六圆 16 日路令

第七 圖 19 日踰 우

第 八 圆 18 日路

第 光圆 20 日路 우

第 十 四 22 日籍

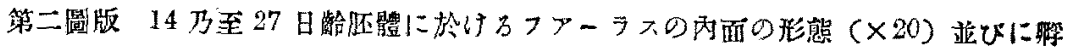

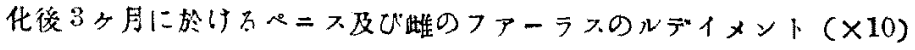

\begin{tabular}{|c|c|}
\hline 第十一罳 & 14 日路全 \\
\hline 第+二四 & 15 日路宫 \\
\hline 第十三圆 & 18'日紫合 \\
\hline 籍十四圖 & 20 日路 5 \\
\hline 第十五圆 & 19 日路 우 \\
\hline 第十六踢 & 22 日䠛 \\
\hline 第十七圖 & 20 日部合 우 \\
\hline 筑十八圆 & 25 日摛 우 \\
\hline 第十九四 & 25 日路古 \\
\hline 第二十喝 & 27 日路合 \\
\hline 第二十一圆 & 眎化後 $3 ヶ$ 里 \\
\hline 第二十二圆 & 娐化後 3 力月 \\
\hline
\end{tabular}




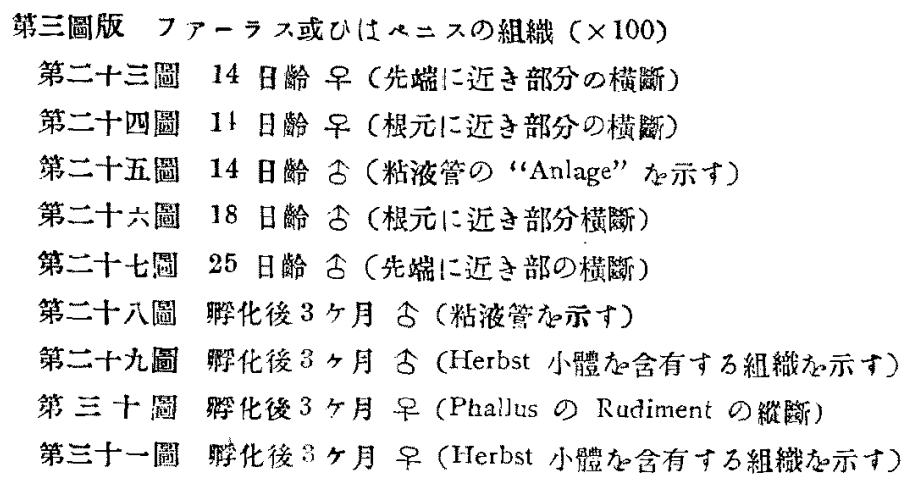

\title{
On The Copulatory Organ Of The Drake, With Special Reference To The Rudimentary Phallus of The Duck.
}

\author{
By \\ Dyuró Hasimoto.
}

It is well known that a drake has a large electile copulatory organ. In the early embryonic stages, the phallus, from which the copulatory organ developes, is found at orifice of the cloacal opening, not only in the male but also in the female embryo. It is identical with the penis of the mammalian embryo in structure, which consists of three parts, i. e., a clitoris and a pair of labia minor.

At about 14-15 days of incubation, there is indication of the phallus beginning to form a spiral comformation, especially in the male embryo, which is characteristic of the penis of the bird. It shows a marked development in the male, and becomes to appear really in a spiral-formed penis at about 22 days of incubation. In the female embryo, however, the comformation of the phallus remains without any further change or development. At the time 
of hatching, the rudimentary phallus of the female is very small in size, i. e., about $0.5 \mathrm{~mm}$. in height at its clitoris and so many breadth at its basal portion, while the length of the penis is about $4.0 \mathrm{~mm}$.

Three or four months after hatching, when the bird reaches almost an adult size, its penis does not yet show its full development. It is so small as $10-15 \mathrm{~mm}$. (in length). Four or five months of age, the penis begins to develope and rapidly attains its full size, i. e., $70-80 \mathrm{~mm}$. (in length), whilst the rudimentary phallus of the female remains as a small raised body and its dimension shows only about $2.0 \mathrm{~mm}$. in height at its clitoris and about $2.5 \mathrm{~mm}$. breadth at its basal portion.

The histological structure of the penis, which is of almost fibrous tissue, appears loose, and many small lymphatic cavities can be rccognised, which are filled with lymph when the penis swells up. In the central part of the tissue, there is a longitudinal canal called a "Drüsenschlauch", which has developed from the depression at the end of the "Geschlechtrinne" of the phallus in the carly embryonic stage, opening at the top of the penis and ending blind at its base. In the rudimentary phallus of the female, this blind canal disappears after hatching, but the lymphatic cavities are still to be recognised, which are filled with lymph when the penis swells up. In the central part of the tissue, there is a longitudinal canal called a "Drüsenschlauch", which has developed from the depression at the end of the "Geschlechtrinne" of the phallus in the early embryonic stage, opening at the top of the penis and ending blind at its base. In the rudimentary phallus of the female, this blind canal disappears after hatching, but the lymphatic cavities are still to be recognised. Herbst corpuscles, the nerve end organs are abundantly found in the tissue of the labia minor of the rudimentary phallus of the female as well as in that of the basal portion of the penis. 


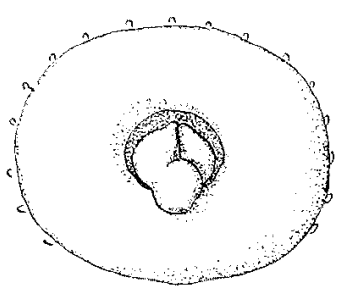

第一圖

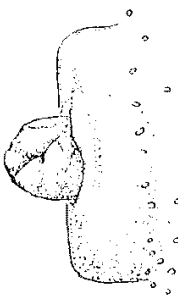

第二圖
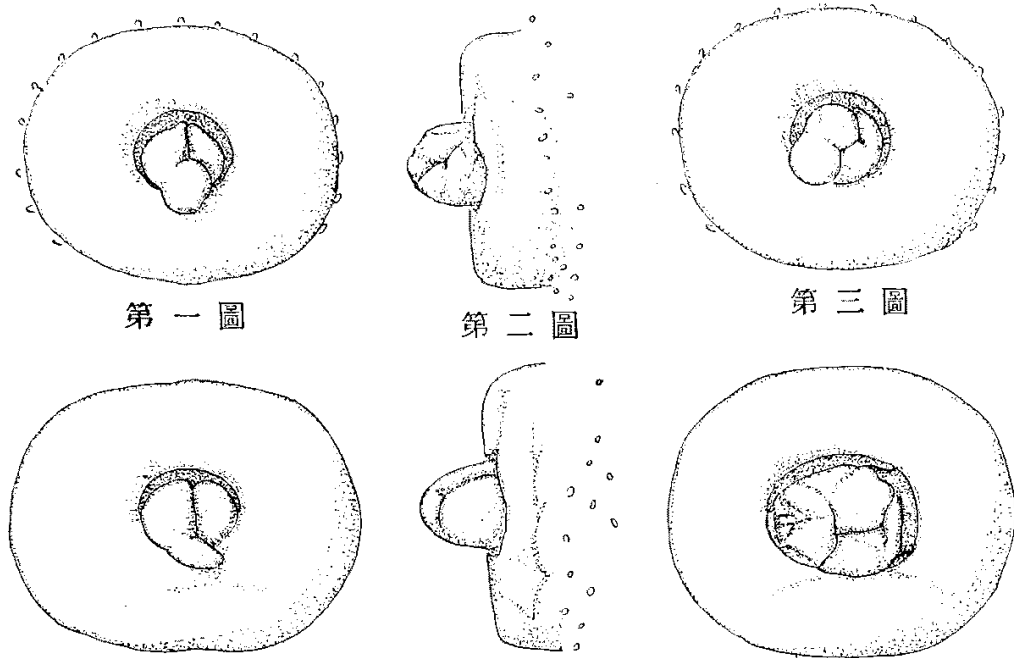

第四圖

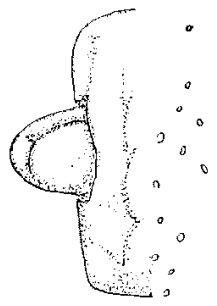

第五圆

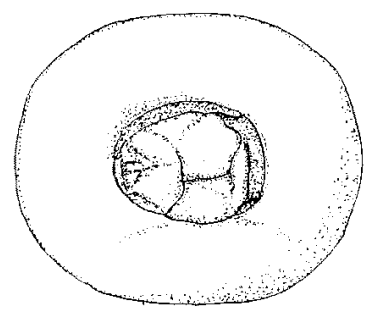

第六圖
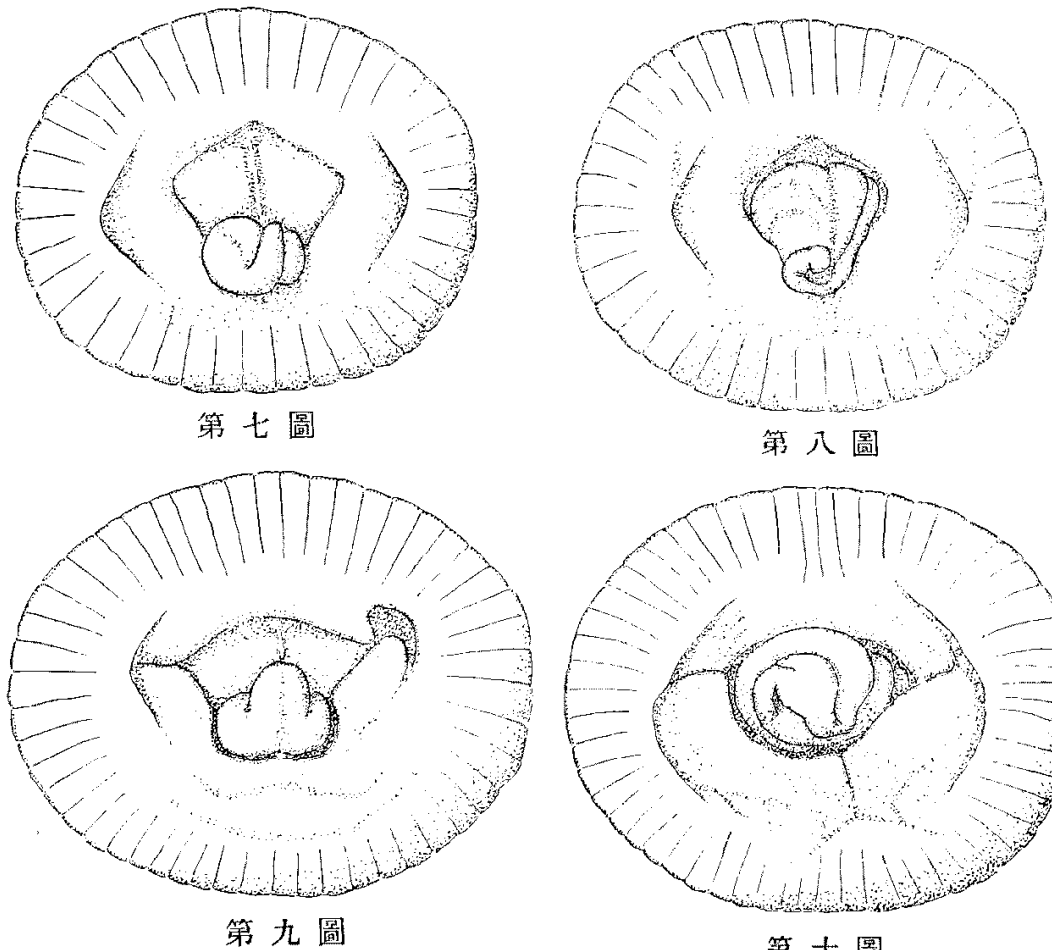

第八圖

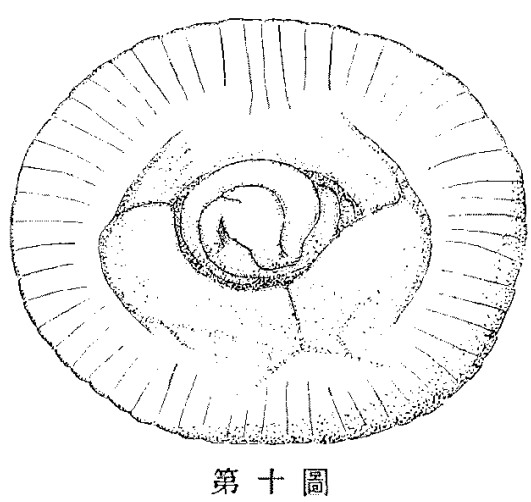




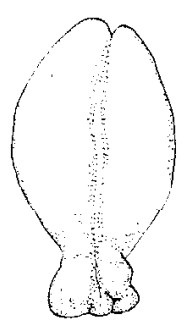

第十一圖
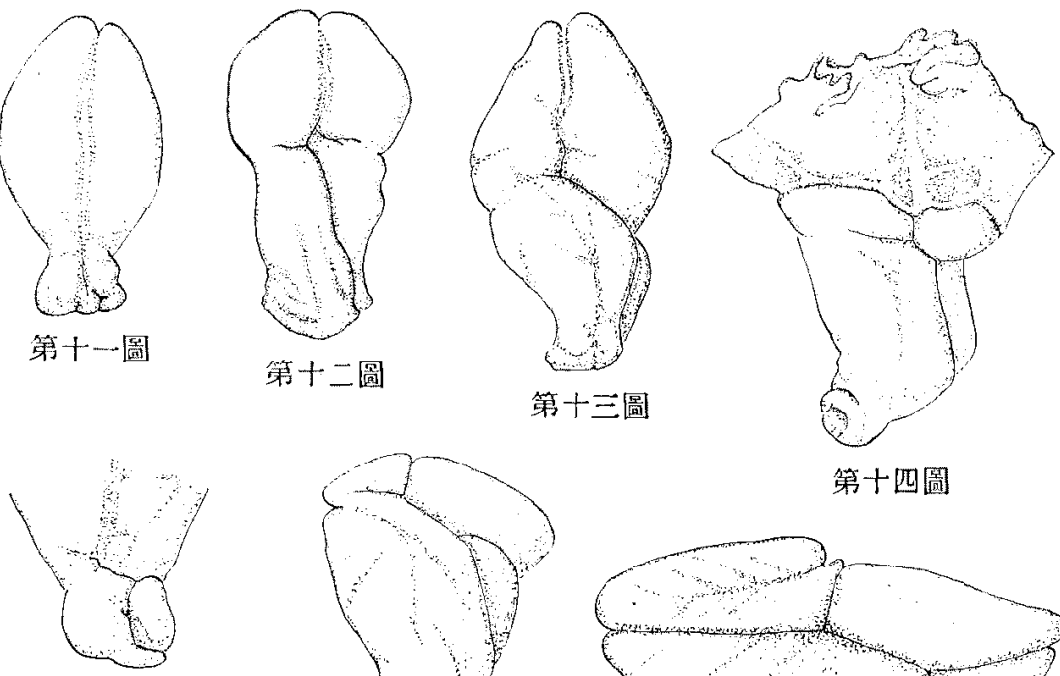

第十五圖

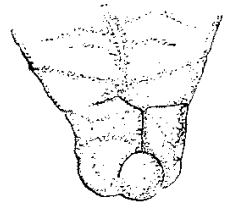

第十七圖

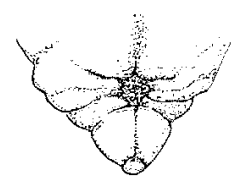

第十八圖

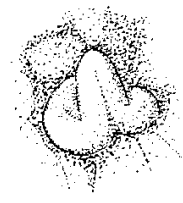

第二十一圖

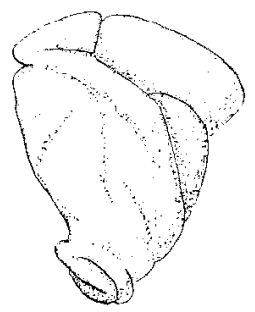

$$
\text { 第十六圖 }
$$

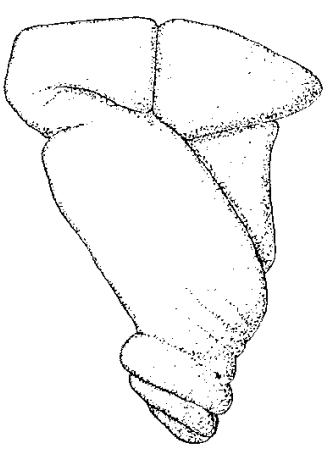

第十九圖

第十四圖

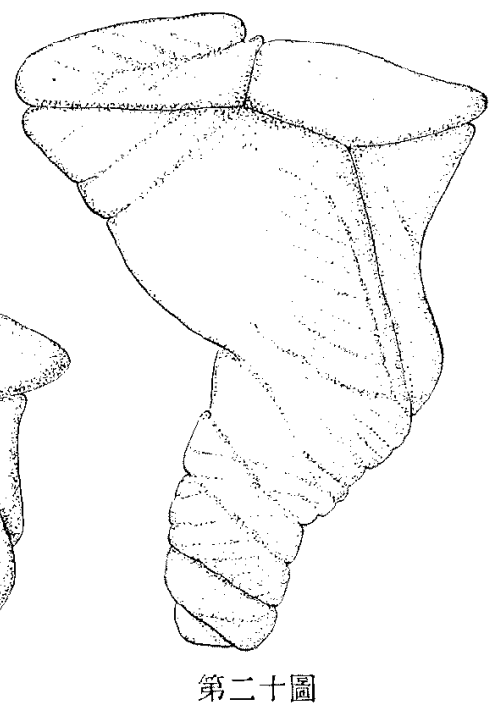

$$
\text { 第二十圖 }
$$

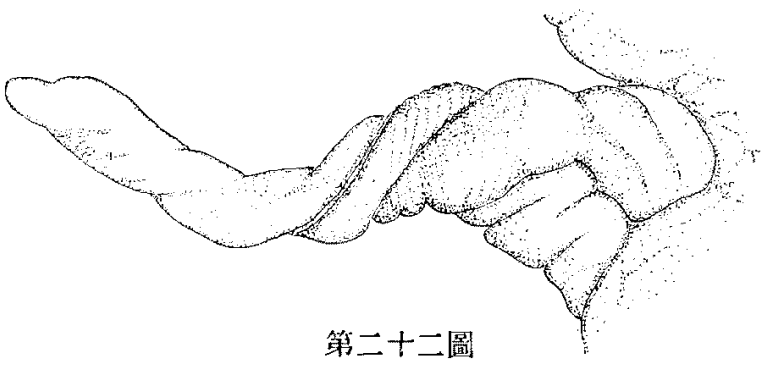




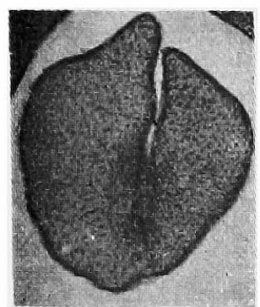

第二十三圖

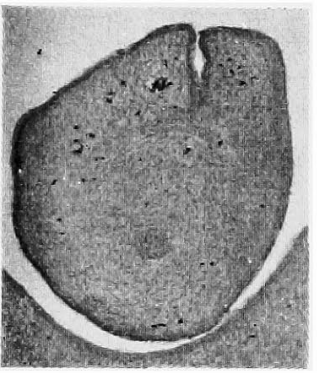

第二十六圖

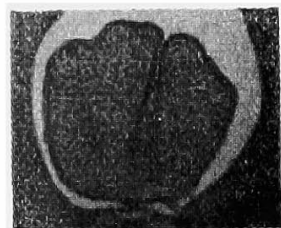

第二十叫圖

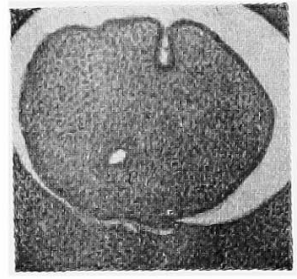

第二十五圖

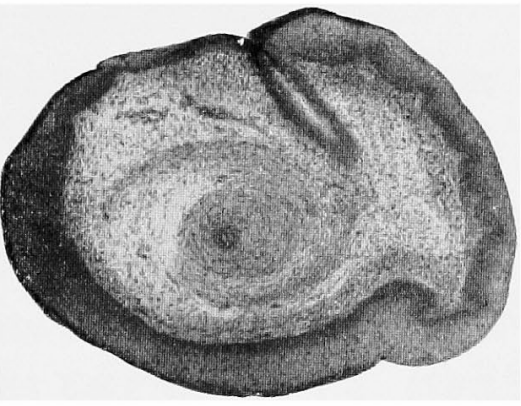

第二十七圖

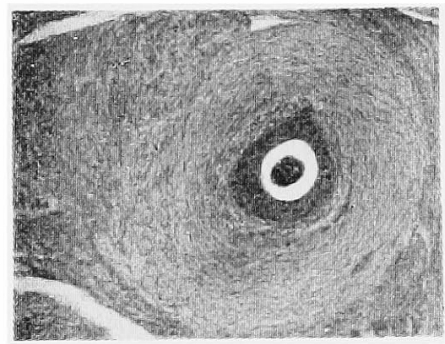

第二十八圖

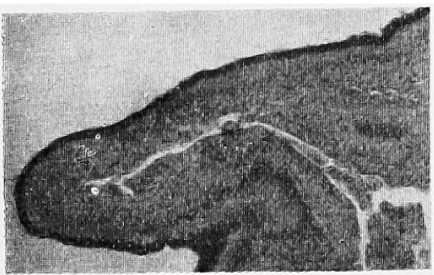

第三十圖

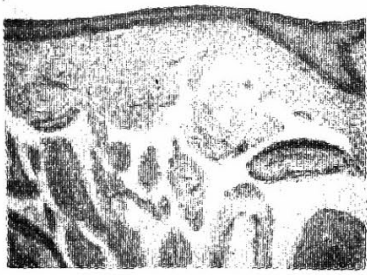

第二十九圖

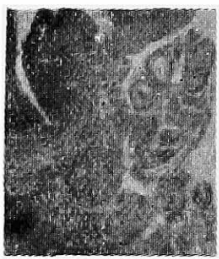

第三十一圖 